\title{
ACUTE AND SUBCHRONIC EVALUATION OF HYDROETHANOLIC EXTRACTS OF NEWBOULDIA LAEVIS (BIGNONIACEAE) AND NAUCLEA LATIFOLIA (RUBIACEAE) ROOTS USED SINGLY OR IN COMBINATION IN NIGERIAN TRADITIONAL MEDICINES IN VARIOUS DISEASES MANAGEMENT
}

\author{
(C) Ogbonnia S. O. ${ }^{1}$, Mbaka G. O. ${ }^{2}$, Enwuru V. N. ${ }^{3}$, \\ Okpagu N. C-S. ${ }^{1}$, Ota D. A. ${ }^{4}$, Nkemehule F. E. ${ }^{1}$
}

\begin{abstract}
'Department of Pharmacognosy, Faculty of Pharmacy, Idi-Araba, University of Lagos, Nigeria ${ }^{2}$ Department of Anatomy, College of Medicine, Lagos State University, Ikeja, Nigeria

${ }^{3}$ Department of Clinical Pharmacy and Biopharmacy, Faculty of Pharmacy, University of Lagos, Idi-Araba, Nigeria ${ }^{4}$ Department of Physiology, College of Medicine, University of Lagos, Idi-Araba, Nigeria
\end{abstract}

The evaluation of the acute and subchronc toxicities of hydroethanolic extracts of Newbouldia laevis and Nauclea latifolia, roots, used extensively in Nigerian herbal preparations singly or in combination to treat various disease states was carried out on Swiss albino mice and Wistar rats of both sexes respectively. The respective extracts and in (1:1) combination, in the dose ranging between $1.0 \mathrm{~g}$ to $20.0 \mathrm{~g} / \mathrm{kg}$ body weight were administered orally to the mice $(22.5 \pm 2.5 \mathrm{~g})$ and observed continuously for the first $4 \mathrm{~h}$ and hourly for the next $12 \mathrm{~h}$, then 6 hourly for $56 \mathrm{~h}$ ( $72 \mathrm{~h}$, acute toxicity) as described by Ogbonnia et al. (1). Wistar rats $(150 \pm 10 \mathrm{~g})$ were also fed with different doses $(100,250$ and $500 \mathrm{mg} / \mathrm{kg}$ bwi) daily of the respective extracts and their (1:1) combination for 30 days as described by Ogbonnia et al. (2). The extracts and their (1:1) mixture effects on some vital organs - heart, liver, testes and kidney - were histologically evaluated. Also the effects on the biochemical and haematological parameters were evaluated (subchronic toxicity model). The result showed that all the animals treated with $20 \mathrm{~g} \mathrm{~g} / \mathrm{kg}$ body weight of the extracts or their (1:1) combination survived beyond 24hrs. While the combination significantly $(p<0.05)$ reduced cholesterol levels, the individual extracts significantly $(p<0.05)$ increased the cholesterol levels. Triglycerides levels were significantly $(p<0.05)$ lowered by $N$. laevis and the mixture but increased by $N$. latifolia. A significant $(p<0.05)$ decrease in the plasma glucose and low density lipoprotein (LDL)-cholesterol levels, and increased high density lipoprotein (HDL)-cholesterol levels were observed in all the treated groups compared to the control. No significant increase in the body weight was observed in the treated groups. A significant $(p<0.05)$ decreased in Aspartate aminotransferases (AST) and Aminotransferases (ALT) levels was observed in all treated groups especially in the group treated with the mixture at a high dose. The photomicrographs of the organs - liver, kidney and heart- treated with $500 \mathrm{mg} / \mathrm{kg}$ body weight of the combination indicated no abnormalities while the liver of the animals treated with $N$. laevis extract $(500 \mathrm{mg} / \mathrm{kg}$ body) showed slight hypertrophy of hepatocytes with apparent congestion at the sinusoidal spaces otherwise no other changes occurred. Also the renal corpuscles of the kidney treated with the same dose of $N$. laevis appeared partially shrunken with increase in Bowman's space. Cellular changes were not apparent while no abnormalities were observed in the heart and testes. There were no abnormalities observed in the photomocrographs of the testes, heart, liver and kidney of the animals treated with Nauclea latifolia $(500 \mathrm{mg} / \mathrm{kg}$ bodyweight) root extract. No significantly $(p \geq 0.05)$ increase in the $H b, R B C$ and PCV values were observed in animals treated with the extract combination compared to the control.

References: (1) Ogbonnia1 Steve O, Mbaka Godwin O Anyika, Emmanuel N., Emordi Jonathan E and Nwakakwa Ndubuisi (2011) An Evaluation of Acute and Subchronic Toxicities of a Nigerian Polyherbal Tea Remedy Pakistan Journal of Nutrition 10 (11): 1022-1028. (2) Ogbonnia SO, Mbaka GO, Anyika EN, Osegbo OM and Igbokwe $\mathrm{NH}$ (2011). Evaluation of acute toxicity in mice and subchronic toxicity of hydroethanolic extract of Chromolaena odorata (L.) King and Robinson (Fam. Asteraceae) in rats. 